\title{
An Observation of the Spring 2006 Migration of Black Scoter Melanitta nigra, in Northumberland Strait, Interrupted by the Confederation Bridge, New Brunswick - Prince Edward Island
}

\author{
Colin MacKinnon and Andrew Kennedy
}

Canadian Wildlife Service, Atlantic Region, P. O. Box 6227, Sackville, New Brunswick E4L 1G6 Canada

MacKinnon, Colin, and Andrew Kennedy 2006. An observation of the spring 2006 migration of Black Scoter Melanitta nigra, in Northumberland Strait, interrupted by the Confederation Bridge, New Brunswick - Prince Edward Island. Canadian Field-Naturalist 120(2): 233-234.

An observation from the bridge of a flock of Black Scoters suggests that, nine years after construction, the $12.9 \mathrm{~km}$ Confederation Bridge may still be a partial barrier to bird migration. Only 3 of 18 scoters $(16.7 \%)$ crossed over the structure during the observation period.

Key Words: Black Scoter, Melanitta nigra, seaducks, migration, Confederation Bridge, Northumberland Strait, New Brunswick, Prince Edward Island, Cape Jourimain National Wildlife Area.

Construction of the Confederation Bridge began in 1995 and was completed in 1997 . This $12.9 \mathrm{~km}$ concrete structure spans the Northumberland Strait at its narrowest point between the Cape Jourimain National Wildlife Area, New Brunswick, and Borden, Prince Edward Island. As part of collecting pre-construction baseline data in 1990, MacKinnon et al. (1991) monitored seabird and seaduck movement through the Northumberland Strait. Twenty-two hours of surveys, during spring and fall, produced 5214 observations on 25 species. Of these, $2041(39.1 \%)$ were seaducks, $1400(26.9 \%)$ were three species of scoters and 641 $(12.3 \%)$ were Common Eider, Somateria mollisima (MacKinnon et al. 1991).
During the early 1990s, concerns were expressed over possible effects the Confederation Bridge may have on seabird migration. The closest comparable existing structure was the Canso Causeway, connecting Cape Breton Island with mainland Nova Scotia. Erskine and Smith (1986) reported that, although the causeway was a comparatively low and short structure, Common Eider were believed to have treated the structure as a barrier to flight. A flock of eiders flew parallel to the causeway, gained altitude, and eventually crossed over. The question was, would seaducks do the same with the Confederation Bridge?

In 1997, Hicklin and Bunker-Popma (2001) conducted surveys at Confederation Bridge during spring 
migration, similar to those reported by MacKinnon et al. (1991). The Confederation Bridge was then operational, and their observations suggested that it formed a partial barrier to scoter migration. Of 3986 and 1441 scoters observed by them during respective spring and fall migration, only $12.8 \%$ of scoters crossed over the bridge during the spring and slightly more, $21.9 \%$, in the fall. Bunker-Popma (2006) subsequently reported additional years of observation.

The Confederation Bridge utilizes a multi-span concrete box girder structure and is composed of three main components: the approaches (east and west), a $40 \mathrm{~m}$ high deck and $60 \mathrm{~m}$-high ship-navigation span. The east approach is $0.6 \mathrm{~km}$ over 7 piers and the west approach is $1.3 \mathrm{~km}$ over 14 piers. The main bridge is $11.0 \mathrm{~km} \mathrm{(44}$ piers) in length. In the middle of the bridge is a $2.50 \mathrm{~km}$ navigation section. The typical span, between piers, is $250 \mathrm{~m}$.

The Confederation Bridge has been in operation for nine years. During the morning of 13 April 2006, we observed the behaviour of a flock of Black Scoters, Melanitta nigra, during their northward migration $\left(46^{\circ} 13^{\prime} \mathrm{N}, 63^{\circ} 44^{\prime} \mathrm{W}\right)$. This observation proved more interesting as the authors were travelling across the bridge, by vehicle, at the time and were able to track the flock's activities over most of the crossing. At the time of observation, visibility was excellent, no clouds, $+6^{\circ} \mathrm{C}$ and wind light SSW.

Shortly after we entered the Confederation Bridge from Borden, Prince Edward Island, at 08:10, a flock of 18 Black Scoters was observed flying parallel with and approximately $100 \mathrm{~m}$ south of the Bridge at a height of approximately $40 \mathrm{~m}$ above the water. The flock was observed to rise and approach the bridge deck on three occasions. On two occasions, the flock approached the deck and then veered back to its original flight path, parallel with the Bridge. On the third occasion, the flock gained altitude and, similar to the previous occasions, aborted its attempted flight over the bridge after coming within approximately $50 \mathrm{~m}$ of the structure. However, this time the flock completed a clockwise circle, towards the bridge, in order to regain their original flight path. At the instant in which the flock began this circle, three birds broke from the main group and promptly crossed over the Bridge, behind our vehicle, at a height of approximately $10 \mathrm{~m}$ above the bridge deck. This crossing occurred approximately $4.5 \mathrm{~km}$ from the Prince Edward Island side of the bridge. The velocity of the flock was constant with our driving speeds of about $80 \mathrm{~km} / \mathrm{h}$, until it could no longer be viewed in the vicinity of the navigation channel. While rising over the navigational channel, the scoters remained out of sight below us. We maintained a constant speed of $80 \mathrm{~km} / \mathrm{hr}$ and the flock was immediately re-sighted once we descended from the elevated navigation span. Upon re-locating the flock, we noted that the group had decreased in size, while out of sight, from 15 to 8 birds. We did not observe any scoters coming into view on the north side of the Bridge and assume the missing seven birds did not cross the structure. The remaining eight birds eventually landed in the water approximately $100 \mathrm{~m}$ south of the bridge and $500 \mathrm{~m}$ from the New Brunswick coastline $\left(46^{\circ} 10^{\prime} \mathrm{N}\right.$, $\left.63^{\circ} 49^{\prime} \mathrm{W}\right)$. Observations ceased at 08:25. It is noteworthy that the Confederation Bridge is built in a general "S" curve, thus the flight of the scoter flock was following the contours of the bridge and not a straight line.

This observation demonstrates that nine years after the Confederation Bridge was built, some seaducks, such as Black Scoters, still may perceive the structure as a partial barrier to their northward migration through the Northumberland Strait.

\section{Acknowledgments}

We thank P. Hicklin, K. Davidson and A. J. Erskine for helpful reviews of the manuscript.

\section{Literature Cited}

Bunke-Pompa, K. 2006. Scoter, Melanitta spp., migrations interrupted by Confederation Bridge: an update. Canadian Field-Naturalist 120(2): 232-233.

Erskine, A. J., and A. D. Smith. 1986. Status and movements of Common Eiders in the Maritime Provinces. Pages 20-29 in Eider Ducks in Canada. Edited by A. Reed. Canadian Wildlife Service, Report Series Number 47. 177 pages.

Hicklin, P., and K. Bunker-Popma. 2001. The spring and fall migrations of scoters Melanitta spp., at Confederation Bridge in the Northumberland Strait between New Brunswick and Prince Edward Island. Canadian Field-Naturalist 115: 436-445.

MacKinnon, C. M., R. W. Daury, and R. J. Hicks. 1991. Seabird and seaduck movement through the Northumberland Strait, 1990. Technical Report Number 130. Canadian Wildlife Service - Atlantic Region. 86 pages.

Received 25 April 2006

Accepted 6 February 2007 